\title{
SPATIAL CONTINUITY OF SOIL ATTRIBUTES IN AN ATLANTIC FOREST REMNANT IN THE MANTIQUEIRA RANGE, MG
}

\author{
Continuidade espacial de atributos do solo sob remanescente \\ de Mata Atlântica na Serra da Mantiqueira, MG
}

\author{
Marcela de Castro Nunes Santos ${ }^{1}$, José Marcio de Mello², Carlos Rogério de Mello ${ }^{3}$, Léo Fernandes Ávila ${ }^{3}$
}

\begin{abstract}
The spatial characterization of soil attributes is fundamental for the understanding of forest ecosystems. The objective of this work was to develop a geostatistical study of chemical and physical soil attributes at three depths (D1 - 0-20 cm; D2 - 20-50 cm; D3 - 50-100 cm), in an Experimental Hydrographic Micro-catchment entirely covered by Atlantic Forest, in the Mantiqueira Range region, Minas Gerais. All the considered variables presented spatial dependence structure in the three depths, and the largest degrees of spatial dependence were observed for $\mathrm{pH}$ in the three depths, soil cation exchange capacity potential in D3, soil organic matter in D1 and D3 and clay and soil bulk density in D2. The method most used for the adjustments of semi-variogram models was the Maximum Likelihood and the most selected model was the Exponential. Furthermore, the ordinary kriging maps allowed good visualization of the spatial distribution of the variables.
\end{abstract}

Index terms: Brazilian native forest, geostatistics, soil features.

\section{RESUMO}

A caracterização espacial de atributos do solo é fundamental para o entendimento de ecossistemas florestais. Neste trabalho, objetivoi-se desenvolver um estudo geoestatístico de atributos químicos e físicos do solo em três profundidades $(\mathrm{P} 1-0-20 \mathrm{~cm} ; \mathrm{P} 2-$ 20-50 cm; P3 - 50-100 cm), em uma Microbacia Hidrográfica Experimental inteiramente coberta por Mata Atlântica, na região Serra da Mantiqueira, Minas Gerais. Todas as variáveis consideradas apresentaram estrutura de dependência espacial nas três profundidades, sendo que os maiores graus de dependência espacial foram observados para $\mathrm{pH}$ nas três profundidades, capacidade de troca de cátions potencial do solo em P3, matéria orgânica do solo em P1 e P3 e argila e densidade do solo em P2. O método mais utilizado para ajuste foi o da Máxima Verossimilhança e o modelo mais selecionado foi o Exponencial. Além disso, os mapas de krigagem permitiram boa visualização da distribuição espacial das variáveis.

Termos para indexação: Floresta nativa brasileira, geoestatística, características do solo.

(Received in october 20, 2012 and approved in december 12, 2012)

\section{INTRODUCTION}

One of the main objectives of ecology and native forest management studies has been to investigate the relationships between the distribution and growth of arboreal species populations and the environmental variables that can affect such processes.

However, those relationships are constantly affected by anthropogenic activities. The process of deforestation and loss of diversity of the Atlantic Forest, for instance, possesses complex causes and dynamics, historically impelled by an unequal system of land ownership and by local, national and international trade relationships (GALINDO- LEAL; CAMERA, 2003), that have resulted in human or anthropogenic modified landscapes in the form of agro-mosaics (TABARELLI et al., 2010).
The native forests of the Mantiqueira Range are inserted in agro-mosaics with different soil uses, now most of the forests being restricted to hill top areas and high elevations, which are inadequate for agriculture (RIBEIRO; FREITAS, 2010). For those forests, as in any other ecosystem, the soil is a fundamental component. The soils have a fundamental function for supporting of the life in the ecosystem and they play a vital role in its resilience facing the impacts produced by possible climatic changes. In other words, much more than just a great carbon reservoir, the soil works as mediator of the productivity and sustainability of the environment (RUMPEL; KOGELKNABNER, 2009) and it deserves to be studied intensely.

Keeping in mind the importance of the soils, the complexity of their relationships with the other ecosystem components and the certainty that the ecosystems present

\footnotetext{
${ }^{1}$ Universidade Federal de Lavras/UFLA - Departamento de Ciências Florestais/DCF - Cx. P. 3037 - $37200-000$ - Lavras - MG - Brasil marcelacns@gmail.com

${ }^{2}$ Universidade Federal de Lavras/UFLA - Departamento de Ciências Florestais/DCF - Lavras - MG - Brasil

3Universidade Federal de Lavras/UFLA - Departamento de Engenharia/DEG - Lavras - MG - Brasil
}

Ciênc. agrotec., Lavras, v. 37, n. 1, p. 68-77, jan./fev., 2013 
spatial and temporal variability in biotic and abiotic characteristics (MUMMEY et al., 2010), one of the most appropriate approaches to characterize soil variables is the model based geostatistical spatial analysis, which is an alternative to the classic statistical procedures that assume independence among samples (MELLO et al., 2009).

The soil attributes are not randomly distributed within the ecosystems or in the landscape and they are made up of regionalized variables. As such, some soil samples are more similar than others based on the distance separating their positions. The recognition of this spatial variability is necessary to better understand the spatial distribution of plants and to develop more precise estimates of the soil properties (GONZÁLEZ; ZAK, 1994).

That necessity to understand the spatial behavior of elements of an ecosystem, such as vegetation, organic matter, as well as other soil attributes, has conditioned the use of several spatial prediction methods, going beyond sample points to the construction of continuous surfaces. These methods vary from maps generated by deterministic interpolators, such as Inverse Distance Weighted (MUELLER et al., 2004; ROBINSON; METTERNICHT, 2006) and geostatistical methods, like Ordinary Kriging (SOUZA; MARQUES JÚNIOR; PEREIRA, 2004; HUANG et al., 2005; GOMES et al., 2007; ZANÃO JÚNIOR et al., 2010; ALVARES et al., 2011), Block Kriging (SØE; BUCHMANN, 2005), Sequential Gaussian Simulation (TEIXEIRA et al., 2011) to even more sophisticated methods such as Regression Kriging (LI, 2010) and mixed lineal model based geostatistics (NIAZI; BISHOP; SINGH, 2011).

Despite so many studies about geostatistical procedures applied for soil attributes mapping, there are few studies about the spatial variability of the soil attributes under the influence of mountain forests, mainly in the deeper layers. In that sense, the objective of this work was to do a study of the spatial variability of some chemical and physical soil attributes, fundamental for the understanding of forest ecosystem dynamics, at three depths, in an Experimental Micro-catchment covered by Atlantic Forest, in the Mantiqueira Range, MG.

\section{MATERIAL AND METHODS}

\section{Study area and sampling plan}

The study area consists of an Atlantic Forest remnant located in an Experimental Micro-catchment (EMC) of 13.71 ha, close to the municipal district of Bocaina de Minas, in the Mantiqueira Range region, in southeast
Minas Gerais, between the coordinates $22^{\circ} 07^{\prime}$ and $22^{\circ} 09^{\prime}$ S Latitude and $44^{\circ} 26^{\prime}$ and $44^{\circ} 29^{\prime}$ 'W Longitude (Figure 1). The EMC possesses a super-humid climate by the Thornthwaite classification, meaning highly positive water balance during the whole year and Cwb by the Köppen classification, with cold winters, less humid than the mild and rainier summers (MELLO et al., 2012). It consists of one of the most important Brazilian areas that have springs, being responsible for the drainage of the Grande and Aiuruoca rivers, among others.

The dominant soil in EMC is Dystrophic Haplic Cambisol (Inceptisol) (MENEZES et al., 2009), whose parental material is granite-gneiss, with depth classified as moderately deep $(<1.5 \mathrm{~m})$. Soil samples were collected at 25 points in the EMC for chemical and physical analysis according to Empresa Brasileira de Pesquisa Agropecuária-Embrapa (1997) at the depths: 0-0.20 m (D1), $0.20-0.50 \mathrm{~m}$ (D2) and 0.50-1.00 m (D3). The studied attributes were: $\mathrm{pH}$, soil cation exchange capacity potential (CE), soil organic matter (OM) and clay, since they incorporate a great amount of information on the soil quality in only one value (SKOPURA et al., 2012). In addition to these attributes, soil bulk density was studied, following the same criteria.

\section{Geostatistical analyzes}

We conducted an exploratory study of the five selected soil attributes in each of three depths, in which it was possible to analyze the bias of the variables in function of the longitude and the latitude. Furthermore, it was also possible to observe the behavior of the data related to the form, the distribution and the central tendency (Normality), according to Mello et al. (2008).

After the exploratory analysis, logarithmic transformation of the data was carried out in order to reduce their range and the effect of conflicting data, seeking improvement in the semivariogram adjustments. Then, a variographic study was applied based on the experimental semivariogram, for the variables considered at the three depths. The semivariogram consists in the geostatistical tool that shows the structural nature of a regionalized variable dataset and it is defined starting from the comparison of values taken simultaneously in two points or more points, according to a certain distance.

Following the experimental semivariogram, come the adjustments of the theoretical spatial models. In the present case, the exponential (EXP), spherical (SPH) and gaussian (GAU) models were adjusted by the Ordinary Least Squares (OLS), Weighted Least Squares (WLS) and Maximum 
Likelihood (ML) methods for each attribute and each depth. The models were selected using Cross Validation criterion, which enables the calculation of precision statistics and has, as a principle, the removal of a known datum (observation) and its subsequent re-estimation based on the model generated by the remaining data (PEI et al., 2010). In case of very close errors, the highest Spatial Dependency Degree (SDD) and the visual aspect of the model in the experimental semivariogram (eye-fit method) were also considered. The SDD consists of the ratio between the structural variance (contribution) and the threshold (contribution + nugget effect) and it is usually treated in terms of the semivariance percentage that is explained by the model (MELLO et al., 2008). The selected spatial models allowed interpolation by ordinary kriging of each of five soil attribute in each of the 3 analyzed depths, totalizing fifteen models.

The geostatistical analyses were conducted by means geoR package (RIBEIRO-JUNIOR; DIGGLE, 2001) in the R platform (R DEVELOPMENT COLORS TEAM, 2010) and the final maps in ArcGIS (ENVIRONMENTAL SYSTEMS RESEARCH INSTITUTE-ERSI, 2006) and Surfer 7.0(GOLDEN SOFTWARE, 1999).

\section{RESULTS AND DISCUSSION}

\section{Spatial behavior of soil attributes in EMC}

The mean values of the $\mathrm{pH}$, clay and soil bulk density increase from D1 to D3 while for CE and OM there is reduction (Table 1). The analyzed variables presented a central tendency (distribution approximately normal) and spatial dependence at the considered depths (Figure 2).

In table 2, the parameters of the selected models are presented as well as the respective adjustment methods for the soil attributes under study and the statistics of precision and spatial dependence degree obtained.

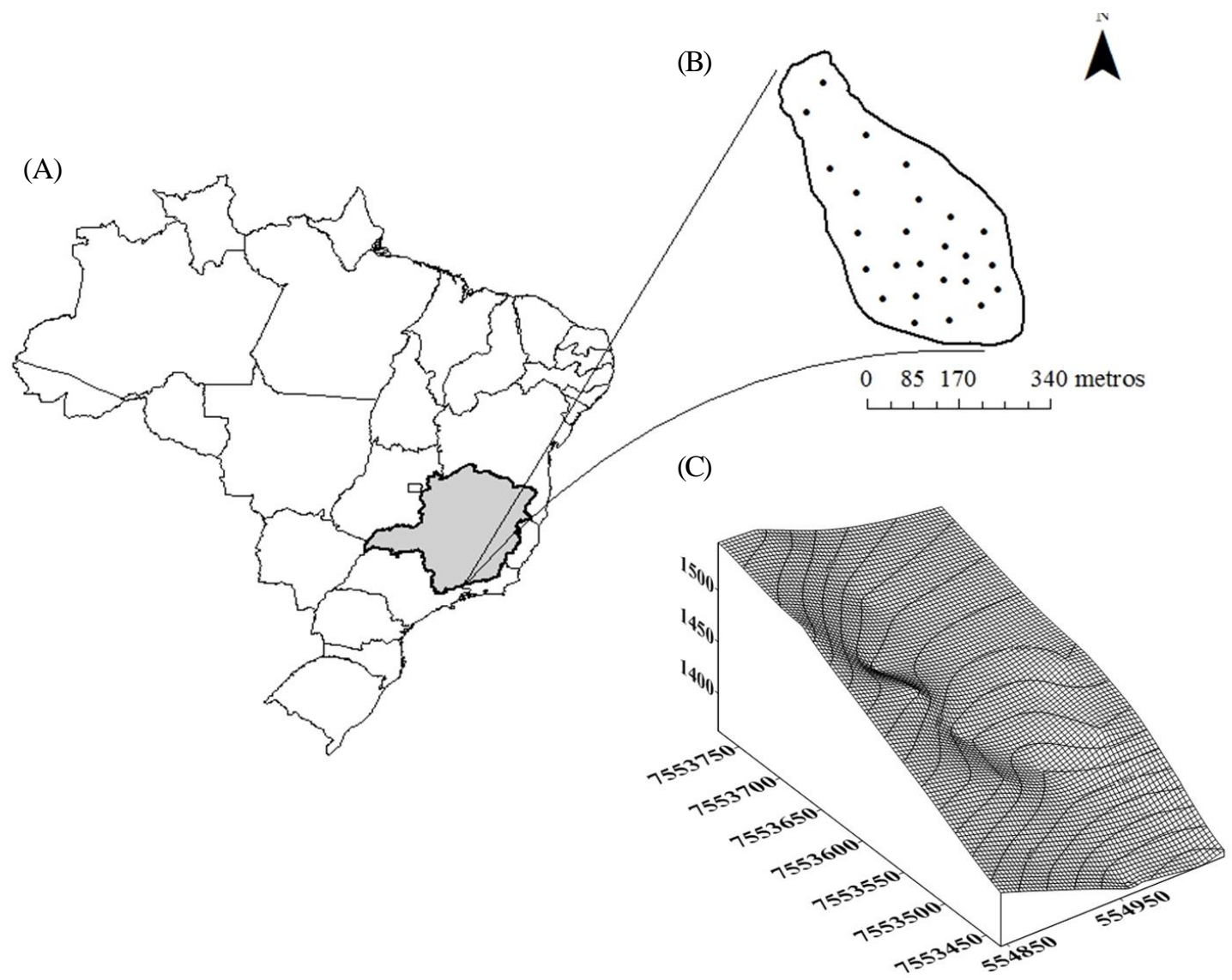

Figure 1 - (A) Location of the study area; (B) the soil sampling points; (C) representation of the slope of the area with isolines spaced by 10 meters.

Ciênc. agrotec., Lavras, v. 37, n. 1, p. 68-77, jan./fev., 2013 
Table 1 - Mean values and soil attribute dispersion measures at three depths.

\begin{tabular}{|c|c|c|c|c|c|c|c|c|c|}
\hline & \multicolumn{3}{|c|}{ D1 } & \multicolumn{3}{|c|}{ D2 } & \multicolumn{3}{|c|}{ D3 } \\
\hline & $\mathrm{M}$ & SD & $\mathrm{CV} \%$ & $\mathrm{M}$ & SD & $\mathrm{CV} \%$ & $\mathrm{M}$ & SD & $\mathrm{CV} \%$ \\
\hline $\mathrm{pH}$ & 4.53 & 0.32 & 7 & 4.73 & 0.29 & 6.06 & 4.87 & 0.27 & 5.48 \\
\hline $\mathrm{CE}$ & 12.27 & 3.32 & 27.03 & 8.15 & 2.36 & 28.94 & 6.63 & 2.34 & 35.22 \\
\hline $\mathrm{OM}$ & 6.08 & 2.58 & 42.47 & 4.58 & 1.53 & 33.44 & 3.43 & 1.45 & 42.45 \\
\hline Clay & 27.46 & 4.51 & 16.43 & 29.92 & 7.5 & 25.07 & 30.96 & 8.83 & 28.54 \\
\hline Density & 0.81 & 0.18 & 21.71 & 0.96 & 0.3 & 30.69 & 1.11 & 0.31 & 28.21 \\
\hline
\end{tabular}

$\left(\mathrm{pH}=\right.$ soil $\mathrm{pH}\left[\mathrm{H}_{2} \mathrm{O}\right] ; \mathrm{CE}=$ soil cation exchange capacity potential $\left[\mathrm{cmol}_{\mathrm{c}} \cdot \mathrm{dm}^{-3}\right] ; \mathrm{OM}=$ soil organic matter $\left[\right.$ dag. $\left.\mathrm{kg}^{-1}\right] ;$ Clay $=$ clay content of the soil [\%]; Density = soil bulk density $\left[\mathrm{kg} \cdot \mathrm{dm}^{-3}\right] ; \mathrm{D} 1=$ soil depth $0-20 \mathrm{~cm}$; D2 = soil depth 20-50 cm; D3 = soil depth 50-100 cm; M = Mean; SD= Sample Standard Deviation; CV= Coefficient of Variation)
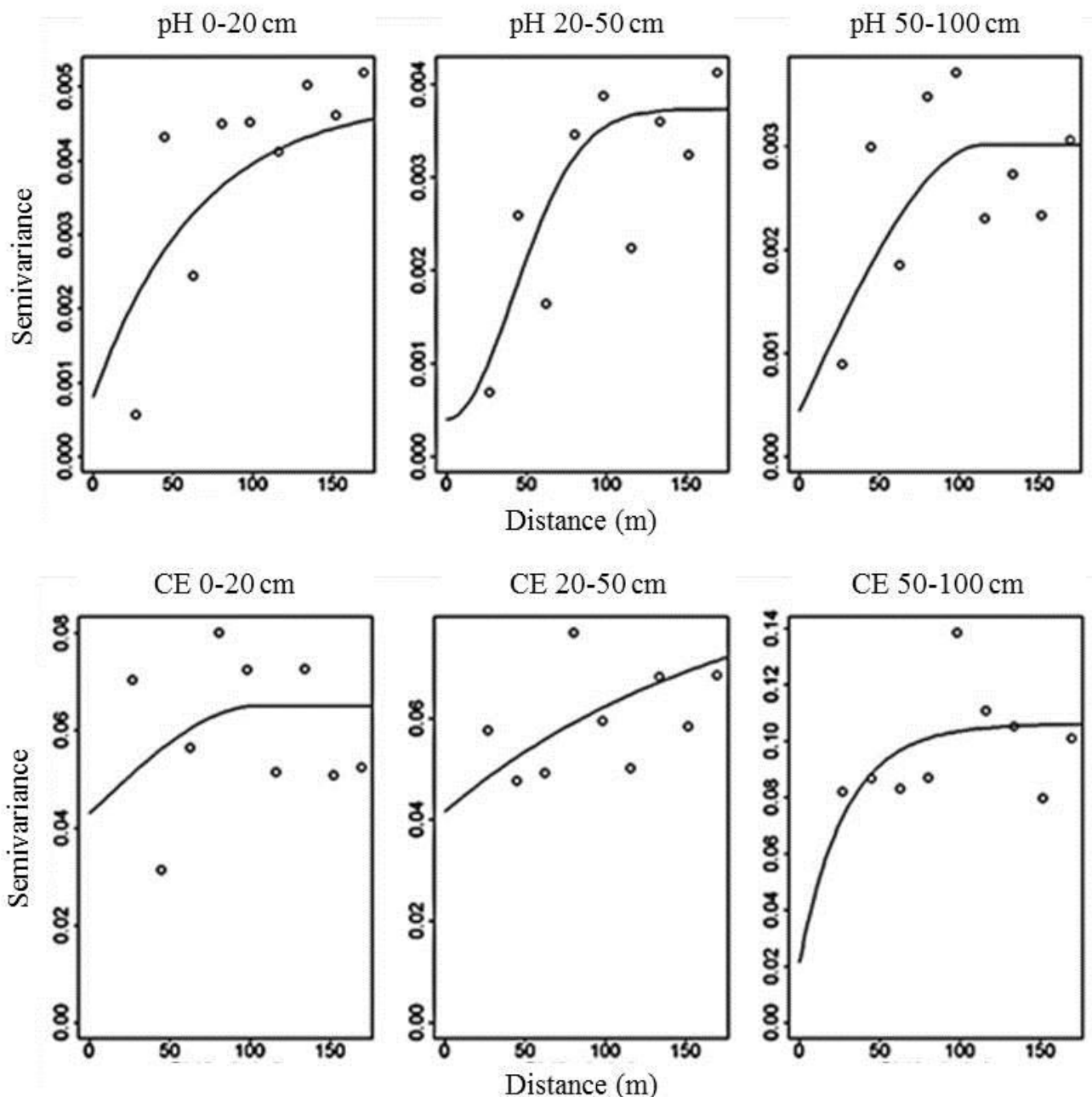

Figure 2 - Experimental semivariograms of the variables studied and the adjusted semivariogram models. $(\mathrm{pH}=\mathrm{soil} \mathrm{pH}$; $\mathrm{CE}=$ soil cation exchange capacity potential at $\mathrm{pH} 7.0 ; \mathrm{OM}=$ soil organic matter; Clay = clay content of the soil; Density $=$ soil density $)$ at the 3 depths considered $(0-20 \mathrm{~cm}, 20-50 \mathrm{~cm}$ and $50-100 \mathrm{~cm})$.

Continued... 

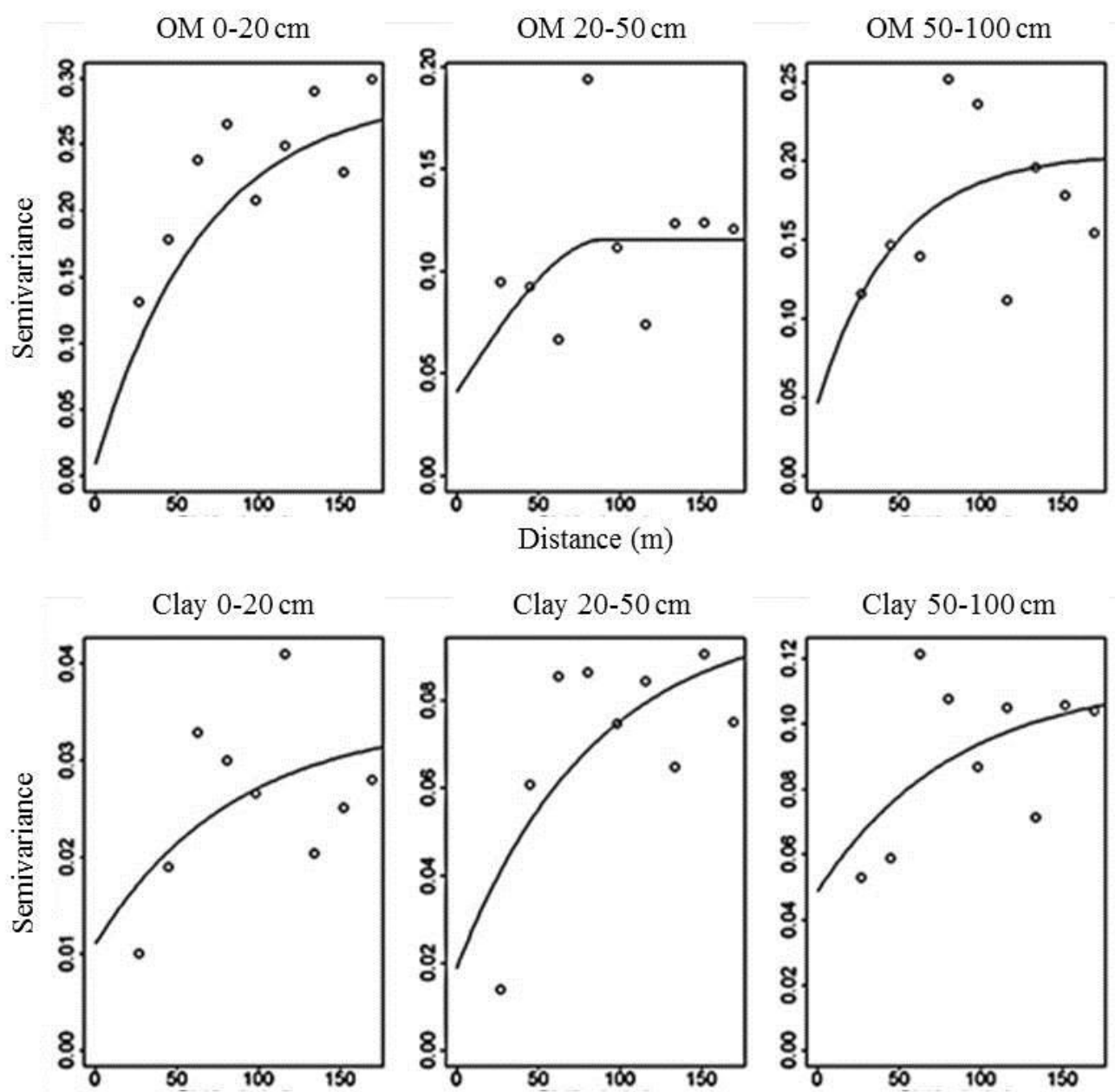

Clay $20-50 \mathrm{~cm}$

Clay $50-100 \mathrm{~cm}$
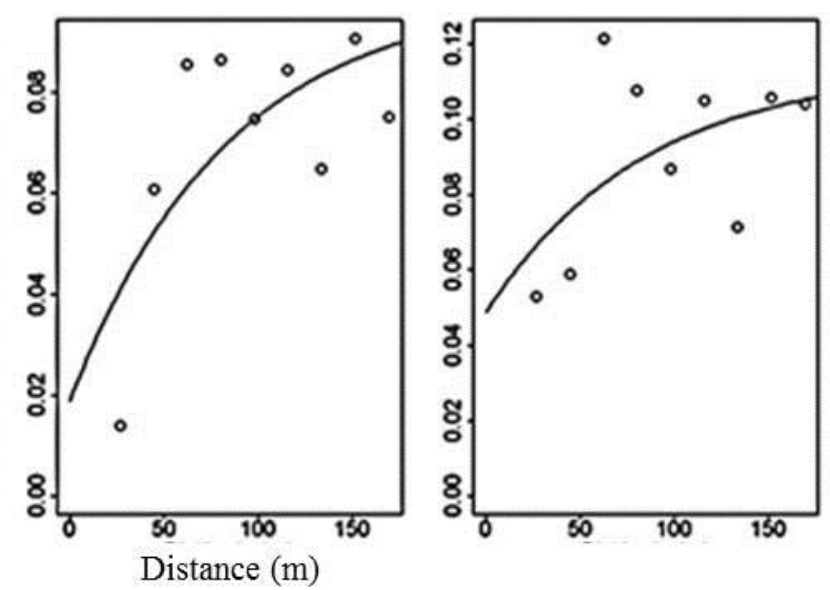

Density $0-20 \mathrm{~cm}$

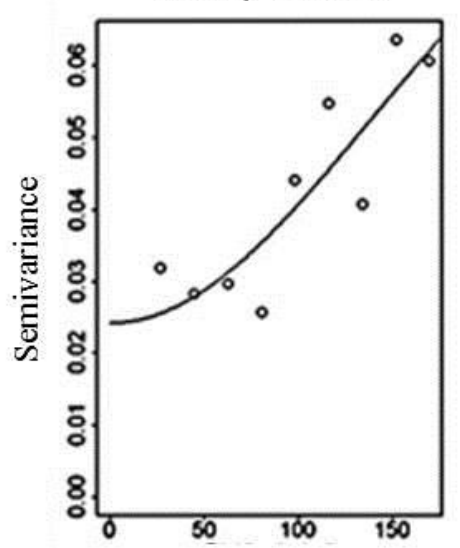

Density $20-50 \mathrm{~cm}$

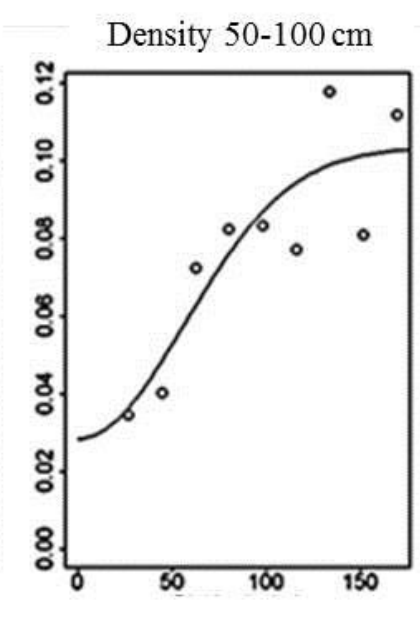

Figure 2 - Continued.

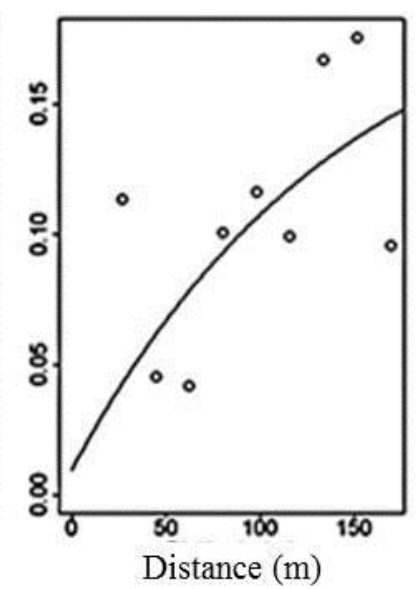

Ciênc. agrotec., Lavras, v. 37, n. 1, p. 68-77, jan./fev., 2013 
Table 2 - Parameters of spatial models selected for the chemical and physical variables of three depths.

\begin{tabular}{ccllllllll}
\hline Var. & Dpth. & Met. & Mod. & NE & C & R & QF & CV & SDD \\
\hline pH & 1 & ML & EXP & 0.0008 & 0.004 & 65.76 & 33.29 & 0.05 & 83.33 \\
pH & 2 & ML & GAU & 0.0004 & 0.0033 & 58.61 & 38.75 & 0.2 & 89.19 \\
pH & 3 & ML & SPH & 0.0004 & 0.0026 & 116.27 & 38.59 & 0.11 & 86.67 \\
CE & 1 & ML & SPH & 0.04 & 0.02 & 105.51 & -0.91 & 0.01 & 33.95 \\
CE & 2 & ML & EXP & 0.04 & 0.05 & 182.47 & -1.6 & 0 & 54.13 \\
CE & 3 & WLS & EXP & 0.02 & 0.08 & 28.55 & 0.06 & 0 & 79.74 \\
OM & 1 & ML & EXP & 0.01 & 0.28 & 66.63 & -14.34 & -0.07 & 96.81 \\
OM & 2 & WLS & SPH & 0.04 & 0.07 & 91.51 & 0.2 & -0.01 & 64.45 \\
OM & 3 & ML & EXP & 0.05 & 0.16 & 47 & -13.26 & -0.03 & 77.4 \\
Clay & 1 & OLS & EXP & 0.01 & 0.02 & 84.17 & 0 & -0.09 & 67.64 \\
Clay & 2 & OLS & EXP & 0.02 & 0.08 & 84.12 & 0 & -0.26 & 81.18 \\
Clay & 3 & OLS & EXP & 0.04 & 0.07 & 84.11 & 0 & -0.08 & 63.64 \\
Density & 1 & WLS & GAU & 0.02 & 0.07 & 194.02 & 0.01 & -0.04 & 74.55 \\
Density & 2 & WLS & EXP & 0.01 & 0.2 & 145.51 & 0.22 & 0.05 & 95.35 \\
Density & 3 & WLS & GAU & 0.03 & 0.08 & 79.84 & 0.03 & -0.1 & 72.53 \\
\hline
\end{tabular}

(pH = soil pH; CE = soil cation exchange capacity potential; $\mathrm{OM}=$ soil organic matter; Clay = clay content of the soil; Density = soil bulk density; Var = Variable; Dpth. $=$ Depth; Met. = Adjustment Method; Mod= Adjusted Theoretical Model; NE $=$ Nugget effect; C = Contribution; R = Reach; QF = Fit Quality Measure, being Residue Sum of the Squares for OLS, Weighted Residue Sum of the Squares for WLS and Maximum log-Likelihood for ML; CV = Error generated by the Cross Validation; SDD = Spatial Dependency Degree).

The most selected model was the Exponential (chosen 9 times), followed by the Gaussian (chosen 3 times) and Spherical (chosen 3 times). According to Cambardella et al. (1994), soil attributes are commonly adjusted to the spherical and exponential models, and the exponential model does not possess a finite reach value, but for practical ends, there is a point starting from which the semivariance stops increasing (WEBSTER, 1985; CABARDELLA et al., 1994) and thus this is the range to be considered.

The highest values of SDD (>75\%) were found for the $\mathrm{pH}$ at all of the depths, CE in D3 and OM in D1 and D3 and Clay and Density in D2. The sample density used in the present work captured a lower spatial dependence for $\mathrm{CE}$ in D1 and D2 (SDD < 50\%). The low correlation among the observations made at different points show that the variance of the regionalized variable is little affected by the distance that separates the observed points, although those variables can have higher spatial dependence on other scales.

According to Cambardella et al. (1994) strong spatial dependence of the chemical and physical soil characteristics is attributed to intrinsic factors such as soil texture and mineralogy, and the weak dependence to the extrinsic factors, such as management and impacts. The study area presents different impact degrees: trails, cattle presence and clearings in different forest sectors, in other words, a reasonably anthropized situation. The lowest area of the forest (altitudes between 1360 and $1400 \mathrm{~m}$ ) presents more impacts, with the highest area (altitudes between 1480 and $1550 \mathrm{~m}$ ) in a better state of conservation. Those different types and degrees of impacts together with the effect of the relief, that is very steepness, can mask the spatial structure of the variables studied on the scale in question.

\section{Mapping of soil attributes and their relationship with the Atlantic Forest}

The selected spatial models permitted the geostatistic interpolation by Ordinary Kriging of the five attributes for the three considered depths (Figure 3).

The soil attributes through the different depths is associated to the pedological aspects of the Mantiqueira Range Cambisol formation (MENEZES et al., 2009) as well as the influence of the Atlantic Forest. From the observation of the kriging maps, it is possible to notice that, at all the depths, areas of lower $\mathrm{pH}$ (more acid soils) coincide with regions of higher CE. Those regions also coincide with those of higher organic matter and intermediate levels of clay content. 

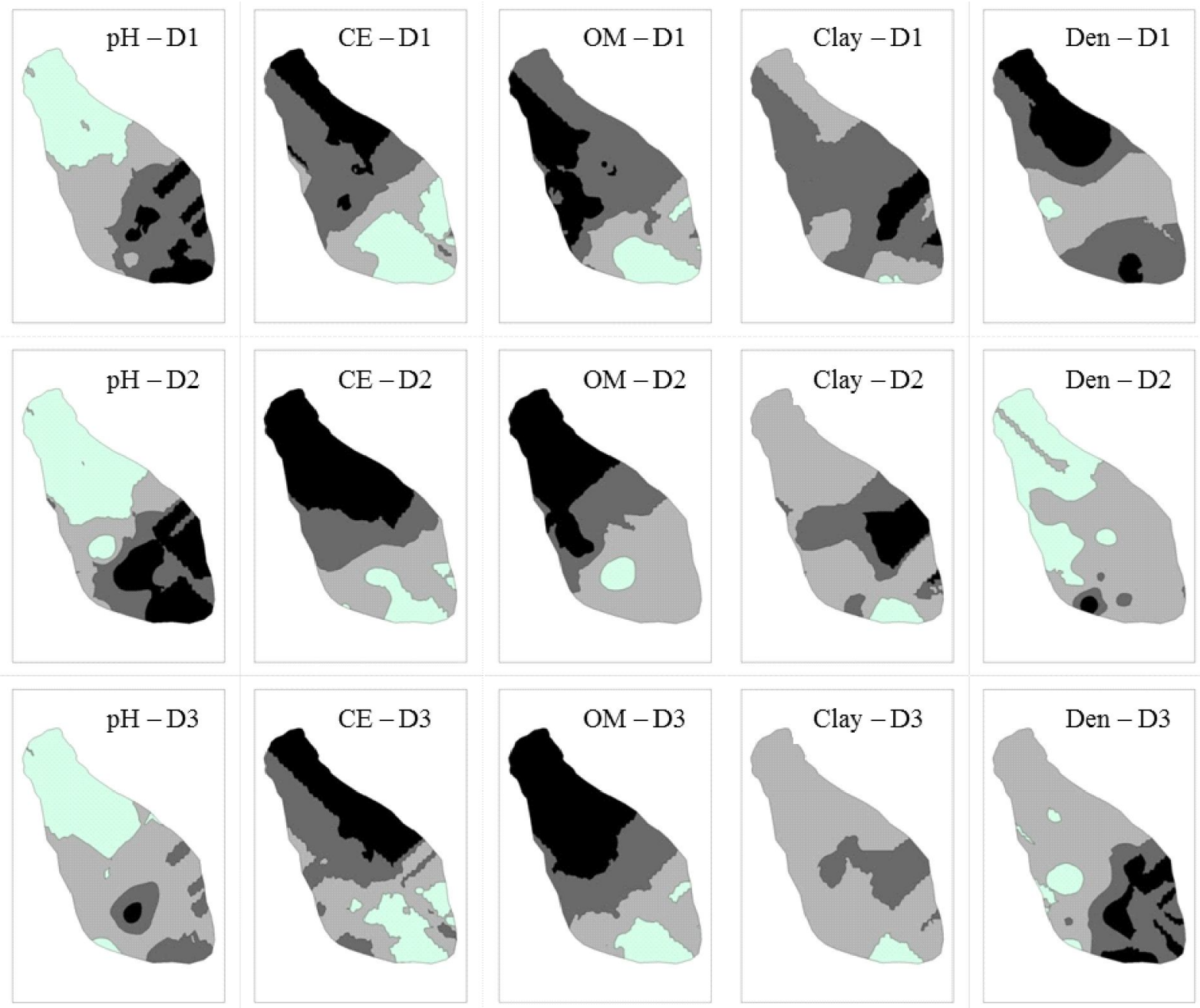

Figure 3 - Ordinary kriging maps of the analyzed variables $(\mathrm{pH}=$ soil $\mathrm{pH} ; \mathrm{CE}=$ soil cation exchange capacity potential at pH 7.0; OM = soil organic matter; Clay = clay content of the soil; Den = soil density) at the 3 depths considered (D1 - 0$20 \mathrm{~cm}$; D2 - 20-50 cm; D3 - 50-100 cm). Lighter tones indicate lower mean values and darker tones higher mean values.

The soil bulk density was that which most presented spatial differences among the depths. Superficially, the soils are denser in the highest regions and in a small portion of the lowest region, reflecting the relief conditions and organic matter accumulation, but at depth they are denser in the lowest regions, close to the stream existent in the area and less dense in the highest regions.

According to Dias et al. (2003), forests in stable conditions in higher altitude regions and under high average precipitation can favor the accumulation of organic matter when the soils possess medium or loamy texture and sufficient plant biomass. In consequence, expressive soil acidification is verified, as is indicated by the lower $\mathrm{pH}$ values in areas of higher OM accumulation. Higher joint clay and OM content present a negative charge balance in the soil and, therefore, higher energy to retain cations (LOPES; GUILHERME, 2004), which increases soil cation exchange capacity potential (CE).

Besides influencing the acidity and the CE of the soil, the organic matter has a fundamental role in nutrient cycling and in their spatial distribution. The litter is the main nutrient transfer pathway from the plants to the soil in forest ecosystems (CUNHA et al., 1993), acting mainly in the transfer of carbon, nitrogen, phosphorous and calcium (COLE; RAPP, 1980) and affecting the microbial 
activity in the soil (KAISER et al., 2010; MUMMEY et al., 2010). As such, the organic matter helps to guarantee the sustainability of the forest ecosystem offering conditions for the formation of preferential flows in the soil profile and, therefore, good conditions groundwater recharge and storage, beyond contributing to the soil protection against the direct impact of intense rains (MENEZES et al., 2009).

In the Mantiqueira Range, forests fragments occur in thicker soils (about $1 \mathrm{~m}$ of depth or more) and little sandy, whose mineralogy is predominantly gibbsitic, that seem to be relics of a mantle of weathering deeper that covered these areas in the past (BENITES et al., 2003) and that, with the forest covering protection from the erosive processes, culminates in a tendency towards higher clay proportions.

Finally, the contribution of the vegetation in relation to the soil nutrients and physical characteristics should especially be considered when the forest areas are impacted. It is noteworthy that, in the case of deforestation, on large or small scale, the carbon is also removed together with the nutrients, influencing the soil organic matter in those locations (MAFRA et al., 2008).

\section{CONCLUSIONS}

All studied variables presented a structure of spatial dependence in all of the depths, and higher SDD and lower cross validation errors were found in the 20-50 $\mathrm{cm}$ depth. The kriging maps generated allowed a better interpretation of the behavior of the variables in the depths evaluated.

\section{REFERENCES}

ALVARES, C. A. et al. Spatial variability of physical and chemical attributes of some forest soils in southeastern of Brazil. Scientia Agricola, Piracicaba, v.68, n 6, p.697705, 2011.

BENITES, V. M. et al Solos e vegetação nos complexos rupestres de altitude da Mantiqueira e do Espinhaço.

Floresta e Ambiente, Seropédica, v.10, n.1, p.76-85, 2003.

CAMBARDELLA, C. A. et al. Field-scale variability of soil properties in central Iowa soils. Soil Science Society of America Journal, Madison, v.58, n.2, p.1501-1511, 1994.

COLE, D. W.; RAPP, M. Elemental cycling in forest ecosystems. In: REICHLE, D. E. (ed.) Dynamic
Properties of Forest Ecosystems. IBP 23. Cambridge

Univ. Press, Cambridge,1980, p.341-410.

CUNHA, G. C. et al. Dinâmica nutricional em floresta estacional decidual com ênfase aos minerais provenientes da deposição da serapilheira. Ciência Florestal, Santa Maria, v.3, n.1, p.35-64, 1993.

DIAS, H. C. T. et al. Caracterização de solos altimontanos em dois transectos no Parque Estadual do Ibitipoca (MG). Revista Brasileira de Ciência do Solo, Viçosa, v.27, p.469-481, 2003.

\section{EMPRESA BRASILEIRA DEPESQUISA}

AGROPECUÁRIA - EMBRAPA. Manual de métodos de análises de solo. 2.ed. Rio de Janeiro, Centro Nacional de Pesquisa de Solos. 1997. 212 p.

\section{ENVIRONMENTALSYSTEMS RESEARCHINSTITUTE} - ESRI. Inc. ArcGIS Professional: GIS for desktop, version 9.3. C.A. 2006.

GALINDO LEAL, C.; CÂMARA, I. DE G. The Atlantic Forest of South America: Biodiversity Status, Threats, and Outlook. Washington: Island Press, 2003.

GOMES, N. M. et L. Variabilidade espacial de atributos físicos do solo associados ao uso e ocupação da paisagem. Revista Brasileira de Engenharia Agrícola e Ambiental, Campina Grande, v.11, n.4, p.427-435, 2007.

GONZALEZ, O. J.; ZAK, D. R. Geostatistical analysis of soil properties in a secondary tropical dry forest, St. Lucia, West Indies. Plant and Soil, Berlin, v.163, p. 45-54, 1994.

HUANG, S. W. et al. Spatial variability of soil nutrients and influencing factors in a vegetable production area of Hebei Province in China. Nutrient Cycling in

Agroecosystems, Dordrecht, v.75, n.1-3, p.201-212, jul. 2006.

KAISER, C. et al. Belowground carbon allocation by trees drives seasonal patterns of extracellular enzyme activities by altering microbial community composition in a beech forest soil. New Phytologist, Oxford, v.187, n.3, p.843-58, ago. 2010. 
LI, Y. Can the spatial prediction of soil organic matter contents at various sampling scales be improved by using regression kriging with auxiliary information? Geoderma, Amsterdam, v.159, p.63-75, oct. 2010 .

LOPES, A. S.; GUILUERME, L. R. G. Interpretação de análises de solo: Conceitos e aplicações. ANDA Associação Nacional para Difusão de Adubos, São Paulo, Boletim Téc., Ed. revisada, p.48, 2004.

MAFRA, Á. L. et al. Carbono orgânico e atributos químicos do solo em areas florestais. Revista Árvore, Viçosa, v.32, n.2, p.217-224, 2008.

MELLO, C. R. et al. Continuidade espacial de chuvas intensas no estado de Minas Gerais. Ciência e Agrotecnologia, Lavras, v.32, n.2, p.532-539, 2008.

MELLO, J. M. et al. Continuidade espacial para características dendrométricas (número de fustes e volume) em plantios de Eucalyptus grandis. Revista Árvore, Viçosa, v.33, n.1, p.185-194, 2009.

MELLO, C. R. et al. Sea surface temperature (SST) and rainfall erosivity in the Upper Grande River Basin, Southeast Brazil. Ciência e Agrotecnologia, Lavras, v.36, p.53-59, 2012.

MENEZES, M. D. et al. Dinâmica hidrológica de duas nascentes, associada ao uso do solo, características pedológicas e atributos físico-hídricos na sub-bacia hidrográfica do Ribeirão Lavrinha - Serra da Mantiqueira (MG). Scientia Forestalis, Piracicaba, v.37, n.82, p.175184, 2009.

MUELLER, T. G. et al. Map quality for ordinary kriging and inverse distance weighted interpolation. Soil Science Society of America Journal, Madison, v.68, p.2042-2047, 2004.

MUMMEY, D. L. et al. Spatial analysis reveals differences in soil microbial community interactions between adjacent coniferous forest and clearcut ecosystems. Soil Biology and Biochemistry, Buderim, v.42, n.7, p.1138-1147, jul. 2010.

NIAZI, N. K.; BISHOP, T. F.A; SINGH, B. Evaluation of spatial variability of soil arsenic adjacent to a disused cattle-dip site, using model-based geostatistics.
Environmental Science \& Technology, Columbus, v.45, n.24, p.10463-70, dez. 2011.

PEI, T. et al. Mapping soil organic matter using the topographic wetness index: A comparative study based on different flow-direction algorithms and kriging methods. Ecological Indicators, Amsterdam, v.10, n.3, p.610-619, maio, 2010.

RIBEIRO, K. T.; FREITAS, L. Impactos potenciais das alterações no Código Florestal sobre a vegetação de campos rupestres e campos de altitude. Biota

Neotropica, Campinas, v.10, n.4, p.239-246, 2010.

RIBEIROJÚNIOR., P.J.; DIGGLE, P.J. GeoR: a packagefor geostatistical analysis. R-news, Vienna, v.1, n.2, p.15-18, 2001.

RDEVELOPMENT CORE TEAM. R: A language and environment for statistical computing. Vienna: $R$ Foundation for Statistical Computing, 2003. Disponível em: <www.R-project.org>

ROBINSON, T. P.; METTERNICHT, G. Testing the performance of spatial interpolation techniques for mapping soil properties. Computers and Electronics in Agriculture, Amsterdam, v.50, n.2, p.97-108, fev. 2006.

RUMPEL, C.; KÖGEL-KNABNER, I. Deep soil organic matter - a key but poorly understood component of terrestrial C cycle. Plant and Soil, Bethlehem, v.338, n.12, p. 143-158, maio, 2010.

SKORUPA, A. L. A. et al. M. Propriedades de solos sob vegetação nativa em Minas Gerais: distribuição por fitofisionomia, hidrografia e variabilidade espacial. Revista Brasileira de Ciência doSolo, Viçosa, v.36, p.11-22, 2012.

SOUZA, Z. M. DE; MARQUES JÚNIOR, J.; PEREIRA, G. $\mathrm{T}$. Variabilidade espacial da estabilidade de agregados e matéria orgânica em solos de relevos diferentes.

Pesquisa Agropecuária Brasileira, Brasília, v.39, n.5, p. 491-499, 2004.

SØE, A. R. B.; BUCHMANN, N. Spatial and temporal variations in soil respiration in relation to stand structure and soil parameters in an unmanaged beech forest. Tree Physiology, Oxford, v.25, n.11, p.1427-36, nov. 2005.

GOLDEN SOFTWARE INC. SURFER for Windows, version 7.0. 1999. 
TABARELLI, M. et al. Prospects for biodiversity conservation in the Atlantic Forest: Lessons from aging human-modified landscapes. Biological Conservation, Amsterdam, v. 143, n. 10, p. 2328-2340, out. 2010.

TEIXEIRA, D. B. et al. Krigagem ordinária e simulação sequencial gaussiana na interpolação da emissão de $\mathrm{CO}_{2}$ do solo. Energia na Agricultura, Botucatu, v.26, n.3, p.26-42, 2011.
WEBSTER, R. Quantitative spatial analysis of soil in the field. Advances in Soil Science, London, v.3, p.170,1985 .

ZANÃO JUNIOR, L. A. et al. Variabilidade espacial dos teores de macronutrientes em latossolos sob sistema plantio direto. Revista Brasileira de Ciência do Solo, Viçosa, v.34, p.389-400, 2010. 